\title{
Children with sickle cell disease who are experiencing psychosocial problems concurrently with their mothers: a Nigerian study
}

\section{MF Tunde-Ayinmode}

Department of Behavioural Sciences, University of Ilorin Teaching Hospital, Ilorin, Nigeria

\begin{abstract}
Objective: The objective of the study was to identify children with Sickle cell disease (SCD) who are experiencing psychosocial problems concurrently with their mothers; and comparing the dyads to determine correlation, pattern of correlation and to identify correlating or modifying factors. Method: The psychosocial impact of Sickle cell disease in affected children and their mothers was assessed using semi-structured questionnaire and standardized instruments (The Child Behaviour Questionnaire (CBQ) - Parents' version or Scale A2) for the children and Self Reporting Questionnaire (SRQ) for their mothers) Children with bronchial asthma and some with acute medical illnesses (AMI) and their mothers who were also assessed with the same instruments served as the control population. Results: There was significant correlation between children who were probable cases with psychological problems based on Child Behaviour Questionnaire ( $\mathrm{CBQ}$ score of $\geq 7$ ) and corresponding mothers who were probable cases with psychosocial problems based on Self-Reporting Questionnaire (SRQ score of $\geq 5$ ). Although there were some group-specific factors that influenced this pattern (child and mother having psychosocial problems concurrently) in one or 2 groups of these diseases, none cut across the 3 group. Conclusion: In psychosocial management of physical illnesses, assessment and care should include a focus on families rather than on the affected individual only. In addition, identifying emotional and social dysfunction in a family member should lead to a search in other members; in this way primary prevention or control can effectively be carried out. Finally, identifying more modifiable factors that positively influence this pattern in which child and mother experience psychosocial dysfunction concurrently should be the urgent task of future and larger studies in this environment.
\end{abstract}

Keywords: Concurrent; Child; Mother; Psychosocial problems; Sickle cell disease

Received: 06-09-2008

Accepted: 14-02-2011

doi: http://dx.doi.org/10.4314/ajpsy.v14i5.8

\section{Introduction}

Sickle cell disease (SCD) is one of the commonest chronic medical condition affecting children in Nigeria, with an incidence of about 2-3\%.1,2 It is estimated that 2-3 million Nigerians have $\mathrm{SCD}^{3}$, with adverse psychosocial impact on affected children and their families.

Sickle cell disease consists of a group of genetic disorders characterized by the simultaneous inheritance

\section{Correspondence}

Dr MF Tunde-Ayinmode

PO Box 693, llorin, Kwara State, Nigeria

email: mosunmolaflorence@yahoo.com from both parents of sickle cell genes. The genotype that constitutes SCD, and of primary importance in Africa, are the homozygous sickle cell disease (Hb SS) also called sickle cell anaemia and the heterozgous diseases in which $\mathrm{Hb} \mathrm{S}$ exists in association with another abnormal haemoglobin ( $\mathrm{Hb}$ ) namely sickle cell $\mathrm{Hb} \mathrm{C}$ disease ( $\mathrm{Hb}$ $\mathrm{SC}$ ), Sickle cell thalassaemia disease (SThal), and Sickle cell high persistent foetal haemoglobin disease (S$\mathrm{HPFH})^{1,4}$

The tripartite interaction between the patient, their disease and their social environment including the family, is dynamic and fraught with risks of maladjustment. ${ }^{5-8}$ Chronic physical illnesses are known to provoke psychosocial dysfunction in affected children and their 
families. ${ }^{5-11}$ Some factors recognized as mediating psychosocial dysfunction in physical illness include: nature and severity of disability caused by the disease; mode of management; and degree of social restriction imposed by the disease on the patient, and their family. ${ }^{\text {? }}$ Childhood physical illness impacts greatly on family functioning ${ }^{12-14}$; by virtue of its central role as a socializing agent, the structure and functioning state of the family can affect, and be affected by a child's physical illness. ${ }^{11-15}$

Existing literature on adjustment to physical illnesses indicate that mothers are relied on to provide vital information about the family. This is because mothers are more involved in the daily care of their children, and hence their knowledge about health and how this affects the family. Mothers more often accompany their children to the clinics than fathers ${ }^{7}$, and are therefore in a position to give a better description of the burden of the illness on their families. By virtue of these roles, mothers are more likely going to bear a substantial portion of the psychosocial impact of the disease on the family.

The psychosocial impact of physical illness is a dynamic process, which may replicate. When an individual behaves in a way to change an impact he may simultaneously create another. For example the taking on, of extra work by mother of a SCD child to reduce the financial burden of SCD may mean an increased risk of physical, social and emotional neglect of her family with consequent marital disharmony. Psychosocial impact is considered an issue because it may cause significant distress. ${ }^{6,16}$

Family maladjustment in SCD resulting from disruptions in the accustomed form and role of social interaction, and accompanying psychological tension in the family and its members, has been well documented. ${ }^{12,13,17,18}$ The social constriction associated with caring for the affected child may encroach on the quantity and quality of parental care available for the siblings, with attendant risk of sibling jealousy; while parents' attention for one another may be compromised, and this may in turn increase the risk of marital disharmony.

Furthermore, other social issues like work absenteeism and divided interest in the work place could play out in the life of affected parents further aggravating a difficult situation. Sometimes financial difficulties or even job loss may occur with serious social consequences. ${ }^{12,14,18,19}$ In addition to these social complications, the psychological burden for affected parents could also be substantial: anger, grief, depression, resentment, guilt and fear of early death of affected children are examples of possible psychopathology reported. ${ }^{12,14,18,19}$

Family risk factors for psychiatric disorder in childhood are multiple and additive. ${ }^{20,21}$ The risk of psychiatric disorder increases with the number of such family's adverse factors as marital discord, low social status, large family size and parental psychiatric disorders. ${ }^{21-24}$ It has been reported that children with two family risk factors have a fourfold increase in rate of disorder. $^{21}$

Rates of psychological disorders are higher in children of mothers with mental illness than children of healthy mothers because of less stimulating environment and/ or less quality of parenting caused by these conditions. ${ }^{25,26}$ It can thus be concluded that maternal risk factors reasonably contribute to psychosocial morbidity in children.

In terms of risks of maladjustment, children with physical illnesses whose mothers have psychosocial problems should be more prone to psychosocial maladjustment because they now have a twofold risk (the disease, and the psychosocial problems in their mothers). The parallel should also be true for mothers whose children are found to have psychosocial problems; they should also have a twofold risk of maladjustment. Mothers who have psychosocial problems independent of their children's illnesses could aggravate dysfunction in their physically ill children with psychological disorders. Such child-mother dyad may thus have a triple burden.

Several studies of psychosocial problems of SCD children using standardized instruments have compared them with healthy controls or with children with other chronic disorders. ${ }^{2,12,27,28}$ However, few, if any have compared them with their mothers, suggesting that childmother dysfunction in physical illnesses needs more attention than it presently enjoys. Generally, reports suggest that a reciprocal relationship may in fact exist between children and their mothers when it comes to psychosocial dysfunction. ${ }^{23-25}$ In other words, children and their mothers are more likely to have psychosocial problems concurrently. It is this potential concurrent relationship that this study set out to investigate in sickle cell disease afflicted families.

This study was derived from a parent study ${ }^{29}$ aimed at assessing the psychosocial problems experienced by children with SCD and their families. It reports the findings of the comparison of psychosocial problems of children who have SCD with controls that have bronchial asthma and acute medical illnesses on one hand and psychosocial problems of their mothers on the other hand.

The study sought to establish whether psychosocial dysfunction in children, correlated significantly with dysfunction in corresponding mothers reasonably enough to suggest concordance, and whether there were any modifying factors involved in this pattern.

\section{Methods}

\section{Recruitment and selection of samples}

The parent study ${ }^{29}$ was a controlled investigation involving 100 SCD children, 75 children with bronchial asthma (asthmatics); and some with acute medical conditions (AMI children). These conditions were mostly malaria fever, acute upper respiratory tract infections, acute urinary tract infections, etc. The study also included their mothers. The former was the study group while, the latter two were the control groups. It was carried out at the University of Ilorin Teaching Hospital (UITH) Ilorin, Nigeria. The children were recruited from the Paediatric SCD, and Chest clinics and the Paediatric unit of the General Outpatient Department (GOPD) of the hospital. The GOPD is essentially a primary care unit since all patients visiting the hospital are seen here first, except 
accident and emergency cases.

All consecutive children aged 7-14years and their biological mothers visiting the above clinics, during the period of the study that met the inclusion criteria and gave consent were assessed. Inclusion criteria for study group included: (i) evidence that children have been in steady state (no crises) at least for the two months preceding the study and (ii) that the diagnosis of SCD was confirmed by Haemoglobin Electrophoresis;

For the bronchial asthma group the inclusion criteria included: (i) evidence that the children have not had an attack in the two months preceding the study; and (ii) that the diagnosis of asthma was made at least one year to the time of the study;

For the AMI group the only criterion was that the children did not have SCD, Asthma or any other chronic illness or life threatening condition; all these were excluded on clinical ground. The absence of a history of, and clinical features of sickle cell disease was used to exclude SCD in the asthma and AMI groups. This was done based on knowledge of the natural history of the disease that affected children are unlikely to lack the typical clinical features of the disease by primary school age ${ }^{27}$; which is the lower age limit for this study. This study was approved by the ethics committee of the University of Ilorin Teaching Hospital.

\section{Instruments}

The Child Behaviour Questionnaire (CBQ) - Parents' version or Scale A2) ${ }^{30}$ and the Self-Reporting Questionnaire $(\mathrm{SRQ})^{31}$ were used to assess for psychological problems in the children and in their mothers respectively. Also used was a semi-structured questionnaire developed by the author to gather information on socio-demographic characteristics of the children and their mothers and the effect of the disease on their level of physical, psychological, social and family functioning as guided by existing literature on the subject. 12-14,17,18 Information sought include among others hospital consultation patterns, school days missed per term, hospital admissions, interference with play, domestic work, experiences of discrimination, feeling of inferiority, fear of failure in life and of death; and the effect of illness on family members and on interactions and the nature and degree of support available.

The responses to the questions on social and family functioning were rated as "not at all" or "a little" or "moderately" or "severe". All questions were answered by the children's mothers; except for those on psychosocial functioning in the semi-structured questionnaire which the children answered.

The Child Behaviour Questionnaire (CBQ) is a widely used 31-item screening instrument, which investigates the child's behaviour in the previous 12 months. It has been found to be acceptable, applicable, reliable and valid in different treatment and epidemiological settings. ${ }^{32,33}$ The parent is asked to indicate the extent to which the statement applies to the child, the frequency of occurrence of the behaviour or the degree of its severity. Each item is rated 0-2, (0: does not apply, 1: apply somewhat, 2 : certainly apply). This produces a total score within the range of 0-62. The content evaluation of the emotional and behavioural disorders of childhood by CBQ reveals three clinical diagnostic categories: neurotic, antisocial and mixed disorders. ${ }^{32}$

According to Rutter ${ }^{37}$ in the original study children who scored a total of 13 or more (which is the optimal cut-off point) are designated as showing some disorder. The optimal cut-off point is therefore the threshold score from and above which a child is considered to have psychiatric disorder. An optimal cut-off 7 arrived at in a validation study by Omigbodun ${ }^{34}$ was used in this study. Omigbodun's study was conducted in a General outpatient department (GOPD) setting among predominantly Yorubaspeaking people who live in a setting similar to that of the present study. The study found the optimal cut-off point of 7 as the threshold score that gave the best trade-off between a high sensitivity and a low false positive rate, at this threshold, sensitivity was 0.61 and specificity was 0.74 .

The SRQ was constructed for use in the WHO study on strategies for extending mental health care and was especially designed for screening of psychiatric disturbances in the primary care setting. ${ }^{31}$ The SRQ-1 or 20-item version was used, each item in the questionnaire is answered 'No' or 'Yes' and has a score of 0 or 1 respectively.

SRQ I, was validated in a primary care setting in rural South Western Nigeria and found to effectively discriminate between patients with and without psychiatric morbidity. ${ }^{35}$ This was best done at an optimal cut-off score of 5, which has the optimal sensitivity of $98.8 \%$ and specificity of $90.9 \%{ }^{35}$ This optimal cut-off point of 5 was also adapted ${ }^{36}$ in a study for assessing the prevalence of psychiatric morbidity among attendees of five primary health care centres in five towns of a rural Local Government Area in South Western Nigeria. Based on the similarities in the setting of this study and the present one an optimal cut-off point of 5 was used.

\section{Instrument translation and pilot-testing}

Translation of the instruments and questionnaire to the local Yoruba language and back-translation to English language was undertaken; and the few areas of disparity were harmonised. Both versions of the instruments were pilottested using 25 children ( 10 with SCD, 5 with Asthma and 10 with AMI) selected from two hospitals (other than UITH) in Ilorin. The pilot-testing exercise revealed that most of the items on the measures were comprehensible and easy to complete, and could be administered within 20 to 30 minutes. The author and two trained assistants administered the instruments.

\section{Data analysis}

Data analysis was carried out using EPI-info version 6. Simple frequency tables were obtained and chi-square tests were performed to determine significant differences between various variables and correlates. The preliminary analysis of the rating of effects on the semi structured questionnaire ("a little", "moderately", "severe") yielded invalid chi-square results (that is at least one expected value was less than 5) hence, the effects were merged into "no effect" and "some effects". Statistical significant difference was set at a "p" value $<0.05$. 


\section{Results}

A total of 250 mothers (100 of SCD children; 75 of Asthmatics, 75 of children with AMI) consented to participate in the study along with their affected children brought to the clinics. A few mothers ( 11 of SCD children; 4 of Asthmatics and 9 of children with AMI) declined participation on the grounds of lack of interest, and or time. The diagnostic categories of the AMI children include: malaria $64 \%$, acute respiratory tract infections $21 \%$ and others 15\% (acute urinary tract infections, conjunctivitis, acute tonsillitis and so on). There was no significant statistical difference for socio-demographic characteristics of the children and their mothers across the three disease groups; meaning that they were similar, and therefore, comparable (Table I).

\section{Table I: Socio demographic characteristics of the children and their mothers for both study and control groups}

\begin{tabular}{|c|c|c|c|c|}
\hline VARIABLES & & $\begin{array}{l}S C D \\
n\end{array}$ & $\begin{array}{l}\text { Asthma } \\
n\end{array}$ & $\begin{array}{l}\text { AMl } \\
n\end{array}$ \\
\hline Children's age group (years) & $\begin{array}{r}7-10 \\
11-14\end{array}$ & $\begin{array}{l}49 \\
51\end{array}$ & $\begin{array}{l}40 \\
35\end{array}$ & $\begin{array}{l}39 \\
36\end{array}$ \\
\hline Children's Gender & $\begin{array}{r}\text { Male } \\
\text { Female }\end{array}$ & $\begin{array}{l}52 \\
48\end{array}$ & $\begin{array}{l}40 \\
35\end{array}$ & $\begin{array}{l}41 \\
34\end{array}$ \\
\hline Children's level of education & $\begin{array}{r}\text { Primary } \\
\text { Secondary }\end{array}$ & $\begin{array}{l}49 \\
51\end{array}$ & $\begin{array}{l}40 \\
35\end{array}$ & $\begin{array}{l}39 \\
36\end{array}$ \\
\hline Birth order & $\begin{array}{r}\text { First } \\
\text { Middle } \\
\text { Last }\end{array}$ & $\begin{array}{l}15 \\
45 \\
40\end{array}$ & $\begin{array}{l}16 \\
39 \\
20\end{array}$ & $\begin{array}{l}18 \\
40 \\
17\end{array}$ \\
\hline Person with whom child resides (current custody) & $\begin{array}{r}\text { Both parents } \\
\text { Mother only } \\
\text { Others }\end{array}$ & $\begin{array}{l}80 \\
16 \\
4\end{array}$ & $\begin{array}{l}64 \\
7 \\
4\end{array}$ & $\begin{array}{l}73 \\
2 \\
0\end{array}$ \\
\hline Children's CBQ scores & $\begin{array}{r}\geq 7 \text { ( cases) } \\
<7 \text { (Non-cases) }\end{array}$ & $\begin{array}{l}30 \\
70\end{array}$ & $\begin{array}{l}19 \\
56\end{array}$ & $\begin{array}{l}15 \\
60\end{array}$ \\
\hline Mothers' age group (years) & $\begin{array}{r}25-30 \\
31-35 \\
36-40 \\
>40\end{array}$ & $\begin{array}{l}9 \\
19 \\
37 \\
35\end{array}$ & $\begin{array}{l}10 \\
22 \\
20 \\
23\end{array}$ & $\begin{array}{l}17 \\
14 \\
27 \\
17\end{array}$ \\
\hline Mothers' level of education & $\begin{array}{r}\text { None } \\
\text { Primary } \\
\text { Secondary } \\
\text { Tertiary }\end{array}$ & $\begin{array}{l}38 \\
21 \\
25 \\
16\end{array}$ & $\begin{array}{l}24 \\
12 \\
30 \\
9\end{array}$ & $\begin{array}{l}20 \\
18 \\
22 \\
15\end{array}$ \\
\hline Occupational group of mothers & $\begin{array}{r}\text { Skilled } \\
\text { Semi-skilled } \\
\text { Unskilled }\end{array}$ & $\begin{array}{l}17 \\
22 \\
61\end{array}$ & $\begin{array}{l}14 \\
25 \\
36\end{array}$ & $\begin{array}{l}17 \\
22 \\
36\end{array}$ \\
\hline Mothers' marital status & $\begin{array}{r}\text { Not currently married } \\
\text { Married }\end{array}$ & $\begin{array}{l}7 \\
93\end{array}$ & $\begin{array}{l}5 \\
70\end{array}$ & $\begin{array}{l}1 \\
74\end{array}$ \\
\hline Mothers' years of marriage & $\begin{array}{r}<10 \text { years } \\
\text { 10-20years } \\
>20 \text { years }\end{array}$ & $\begin{array}{l}6 \\
61 \\
32\end{array}$ & $\begin{array}{l}7 \\
47 \\
20\end{array}$ & $\begin{array}{l}9 \\
50 \\
16\end{array}$ \\
\hline Type of family & $\begin{array}{r}\text { Monogamy } \\
\text { Polygamy }\end{array}$ & $\begin{array}{l}60 \\
40\end{array}$ & $\begin{array}{l}51 \\
24\end{array}$ & $\begin{array}{l}53 \\
22\end{array}$ \\
\hline Mothers' number of children & $\begin{array}{r}\leq 5 \\
6-10 \\
>10\end{array}$ & $\begin{array}{l}75 \\
25 \\
0\end{array}$ & $\begin{array}{l}53 \\
22 \\
0\end{array}$ & $\begin{array}{l}53 \\
21 \\
1\end{array}$ \\
\hline Mother SRQ Scores & $\begin{array}{r}\geq 5 \text { (Cases) } \\
<5 \text { (Non-cases) }\end{array}$ & $\begin{array}{l}28 \\
72\end{array}$ & $\begin{array}{l}15 \\
60\end{array}$ & $\begin{array}{l}19 \\
56\end{array}$ \\
\hline
\end{tabular}

$\mathrm{N}=$ Total number of children or mothers in each disease group (SCD=100, Asthma=75, AMI=75)

$\mathrm{n}=$ distribution of $\mathrm{N}$ in the variables examined 
The pattern of selected psychosocial effects of the diseases on the children and their mothers was fairly similar across the disease groups, except that the effects appeared to be somewhat most frequent and severest in the SCD group compared to the controls (Tables II and III). Data from these Tables (II and III) provide evidence that all the diseases have some effect on the children and their mothers

There was a statistically significant association between the children with $\mathrm{CBQ}$ score $\geq 7$ and mothers with SRQ scores $\geq 5$ across the disease groups and when the groups were combined (SCD : 13 of $28 / \mathrm{p}=0.046$; Asthma: 7 of 15/ $\mathrm{p}=0.047$; AMI: 10 of $19 / \mathrm{p}=0.000$ and all groups Combined: 30 of $62 / \mathrm{p}=0.000$ ) (Table IV).

In addition, among the maternal variables tested, family type had significant association with the children's psychological morbidity in the control groups and when all the groups were combined (Asthma $\mathrm{p}=0.014$; AMI: $\mathrm{p}=0.022$ Combined: $\mathrm{p}=0.000$ ) (Table IV).

Also there was significant association between children who were probable cases of psychiatric disorders, and

\begin{tabular}{|c|c|c|c|c|c|}
\hline VARIABLES & & $\begin{array}{l}S C D \\
n\end{array}$ & $\begin{array}{l}\text { ASTHMA } \\
n\end{array}$ & $\begin{array}{l}A M l \\
n\end{array}$ & $P$ value \\
\hline CBQ Scores & $\begin{array}{l}\geq 7 \\
<7\end{array}$ & $\begin{array}{l}30 \\
70\end{array}$ & $\begin{array}{l}19 \\
56\end{array}$ & $\begin{array}{l}15 \\
60\end{array}$ & 0.324 \\
\hline Average school days missed per term & $\begin{array}{l}0-1 \\
\geq 2\end{array}$ & $\begin{array}{l}39 \\
61\end{array}$ & $\begin{array}{l}67 \\
8\end{array}$ & $\begin{array}{l}68 \\
7\end{array}$ & 0.000 \\
\hline No. of hospital visits in 6 months & $\begin{array}{l}0-1 \\
\geq 2\end{array}$ & $\begin{array}{l}36 \\
64\end{array}$ & $\begin{array}{l}61 \\
14\end{array}$ & $\begin{array}{l}59 \\
16\end{array}$ & 0.000 \\
\hline Previous hospital admissions & $\begin{array}{r}\text { None } \\
1 \\
\geq 2\end{array}$ & $\begin{array}{l}24 \\
23 \\
53\end{array}$ & $\begin{array}{l}61 \\
11 \\
3\end{array}$ & $\begin{array}{l}67 \\
5 \\
3\end{array}$ & 0.000 \\
\hline Interference with daily play activities & $\begin{array}{l}\text { Yes } \\
\text { No }\end{array}$ & $\begin{array}{l}67 \\
33\end{array}$ & $\begin{array}{l}45 \\
30\end{array}$ & $\begin{array}{l}29 \\
46\end{array}$ & 0.000 \\
\hline Interference with domestic activities & $\begin{array}{l}\text { Yes } \\
\text { No }\end{array}$ & $\begin{array}{l}57 \\
43\end{array}$ & $\begin{array}{l}37 \\
38\end{array}$ & $\begin{array}{l}28 \\
47\end{array}$ & 0.036 \\
\hline I feel I am a burden to my family & $\begin{array}{l}\text { Yes } \\
\text { No }\end{array}$ & $\begin{array}{l}33 \\
67\end{array}$ & $\begin{array}{l}19 \\
56\end{array}$ & $\begin{array}{l}10 \\
65\end{array}$ & 0.012 \\
\hline I feel I have given my family a bad image & $\begin{array}{l}\text { Yes } \\
\text { No }\end{array}$ & $\begin{array}{l}8 \\
92\end{array}$ & $\begin{array}{l}4 \\
71\end{array}$ & $\begin{array}{l}2 \\
73\end{array}$ & 0.313 \\
\hline I feel that people bother me a lot & $\begin{array}{l}\text { Yes } \\
\text { No }\end{array}$ & $\begin{array}{l}27 \\
73\end{array}$ & $\begin{array}{l}10 \\
65\end{array}$ & $\begin{array}{l}9 \\
66\end{array}$ & 0.016 \\
\hline I feel people discriminate against me & $\begin{array}{l}\text { Yes } \\
\text { No }\end{array}$ & $\begin{array}{l}25 \\
75\end{array}$ & $\begin{array}{l}13 \\
62\end{array}$ & $\begin{array}{l}10 \\
65\end{array}$ & 0.135 \\
\hline I feel my classmates see me as different & $\begin{array}{l}\text { Yes } \\
\text { No }\end{array}$ & $\begin{array}{l}32 \\
67\end{array}$ & $\begin{array}{l}14 \\
61\end{array}$ & $\begin{array}{l}5 \\
70\end{array}$ & 0.000 \\
\hline I find it difficult making friends & $\begin{array}{l}\text { Yes } \\
\text { No }\end{array}$ & $\begin{array}{l}10 \\
90\end{array}$ & $\begin{array}{l}2 \\
73\end{array}$ & $\begin{array}{l}3 \\
72\end{array}$ & 0.089 \\
\hline I feel I have bad luck & $\begin{array}{l}\text { Yes } \\
\text { No }\end{array}$ & $\begin{array}{l}29 \\
71\end{array}$ & $\begin{array}{l}3 \\
72\end{array}$ & $\begin{array}{l}4 \\
71\end{array}$ & 0.000 \\
\hline I feel am inferior to other children & $\begin{array}{l}\text { Yes } \\
\text { No }\end{array}$ & $\begin{array}{l}33 \\
67\end{array}$ & $\begin{array}{l}9 \\
66\end{array}$ & $\begin{array}{l}1 \\
74\end{array}$ & 0.000 \\
\hline I feel I am not likely to achieve much in life & $\begin{array}{l}\text { Yes } \\
\text { No }\end{array}$ & $\begin{array}{l}23 \\
77\end{array}$ & $\begin{array}{l}4 \\
71\end{array}$ & $\begin{array}{l}3 \\
72\end{array}$ & 0.000 \\
\hline I am afraid I may die any time & $\begin{array}{l}\text { Yes } \\
\text { No }\end{array}$ & $\begin{array}{l}47 \\
53\end{array}$ & $\begin{array}{l}22 \\
53\end{array}$ & $\begin{array}{l}10 \\
65\end{array}$ & 0.000 \\
\hline \multicolumn{6}{|c|}{$\begin{array}{l}N=\text { Total number of children in each disease group ( } S C D=100, \text { Asthma=75, } A M l=75 \text { ) } \\
n=\text { distribution of } N \text { in the variables examined }\end{array}$} \\
\hline
\end{tabular}




\begin{tabular}{|c|c|c|c|c|c|}
\hline VARIABLES & & $\begin{array}{l}S C D \\
n\end{array}$ & $\begin{array}{l}\text { Asthma } \\
n\end{array}$ & $\begin{array}{l}A M l \\
n\end{array}$ & $P$ Value \\
\hline Mother's SRQ score & $\begin{array}{r}\geq 5 \text { ( cases) } \\
<5 \text { (Non-cases) }\end{array}$ & $\begin{array}{l}28 \\
72\end{array}$ & $\begin{array}{l}15 \\
60\end{array}$ & $\begin{array}{l}19 \\
56\end{array}$ & 0.475 \\
\hline Financial effect & $\begin{array}{l}\text { Yes } \\
\text { No }\end{array}$ & $\begin{array}{l}94 \\
6\end{array}$ & $\begin{array}{l}58 \\
17\end{array}$ & $\begin{array}{l}39 \\
36\end{array}$ & 0.000 \\
\hline Time Consumption & $\begin{array}{l}\text { Yes } \\
\text { No }\end{array}$ & $\begin{array}{l}89 \\
11\end{array}$ & $\begin{array}{l}48 \\
27\end{array}$ & $\begin{array}{l}38 \\
37\end{array}$ & 0.000 \\
\hline Disease preventing enjoyment of life & $\begin{array}{l}\text { Yes } \\
\text { No }\end{array}$ & $\begin{array}{l}59 \\
41\end{array}$ & $\begin{array}{l}21 \\
54\end{array}$ & $\begin{array}{l}17 \\
58\end{array}$ & 0.000 \\
\hline Ignoring the rest of the family to care for patient & $\begin{array}{l}\text { Yes } \\
\text { No }\end{array}$ & $\begin{array}{l}53 \\
47\end{array}$ & $\begin{array}{l}17 \\
58\end{array}$ & $\begin{array}{l}14 \\
61\end{array}$ & 0.000 \\
\hline $\begin{array}{l}\text { Feeling that other children resent the time spent with the patient } \\
\text { the time spent with the patient }\end{array}$ & $\begin{array}{l}\text { Yes } \\
\text { No }\end{array}$ & $\begin{array}{l}17 \\
83\end{array}$ & $\begin{array}{l}9 \\
66\end{array}$ & $\begin{array}{l}7 \\
68\end{array}$ & 0.311 \\
\hline Extent of first aid cares at home & $\begin{array}{l}\text { Yes } \\
\text { No }\end{array}$ & $\begin{array}{l}84 \\
16\end{array}$ & $\begin{array}{l}53 \\
22\end{array}$ & $\begin{array}{l}52 \\
23\end{array}$ & 0.041 \\
\hline Extent of discussing illness with patient & $\begin{array}{l}\text { Yes } \\
\text { No }\end{array}$ & $\begin{array}{l}76 \\
24\end{array}$ & $\begin{array}{l}45 \\
30\end{array}$ & $\begin{array}{l}27 \\
48\end{array}$ & 0.000 \\
\hline Using illness to seek attention & $\begin{array}{l}\text { Yes } \\
\text { No }\end{array}$ & $\begin{array}{l}9 \\
91\end{array}$ & $\begin{array}{l}7 \\
68\end{array}$ & $\begin{array}{l}5 \\
70\end{array}$ & 0.809 \\
\hline Using illness to manipulate to get wants & $\begin{array}{l}\text { Yes } \\
\text { No }\end{array}$ & $\begin{array}{l}12 \\
88\end{array}$ & $\begin{array}{l}6 \\
69\end{array}$ & $\begin{array}{l}4 \\
71\end{array}$ & 0.092 \\
\hline Extent of overprotection & $\begin{array}{l}\text { Yes } \\
\text { No }\end{array}$ & $\begin{array}{l}79 \\
21\end{array}$ & $\begin{array}{l}34 \\
41\end{array}$ & $\begin{array}{l}22 \\
53\end{array}$ & 0.000 \\
\hline \multicolumn{6}{|c|}{$\begin{array}{l}N=\text { Total number of mothers of children in each group }(S C D=100, \text { Asthma=75 AMl=75) } \\
n=\text { distribution of } N \text { in the variables examined }\end{array}$} \\
\hline
\end{tabular}

mothers who indicated that they felt the financial burden of the diseases (Asthma: $\mathrm{p}=0.054$ ) as well as their time consumption burden (Combined group: $\mathrm{P}=0.041$, (Table IV).

Children who were identified as probable cases of psychiatric disorders by CBQ were significantly associated with mothers also identified as probable cases of psychiatric disorders with SRQ across the disease groups and when combined (SCD: 13 of 30/p=0.046; Asthma: 7 of 19/ $\mathrm{p}=0.048$; AMI: 10 of 15/ $\mathrm{p}=0.000$; Combined: 30 of $64 /$ $\mathrm{p}=0.000$, (Table V). Other selected variables of psychosocial burden assessment in the children that were found to correlate with psychosocial burden of mothers in at least two groups include the following: 'See self as a burden to family' (Asthma: 7 of 19/p=0.048; AMI: 6 of 10/ $p=0.014$ Combined: 23 of $62 / \mathrm{p}=0.016$ ) and 'I feel people discriminate against me' (Asthma: 5 of 10/p=0.023; AMI: 6 of $10 / \mathrm{p}=0.014$ Combined: 20 of $52 / \mathrm{p}=0.017$ ).

\section{Discussion}

This paper intended to identify children with SCD who were experiencing psychosocial problems concurrently with their mothers. A significant number of children with psychosocial problems had corresponding mothers with problems. Incidentally this phenomenon cut across three disease groups separately and when combined (Tables IV and V).

With evidence linking maternal and family risk factors to child psychiatric disorder21-24, concurrent psychosocial problem or morbidity is a reasonable expectation in the setting of physical illness especially chronic types affecting children. By extension, because of the special relationship between mothers and their children a peculiar psychosocial morbidity pattern is logical to expect. Previous attempts have been made to unravel this pattern $11,25,26$, these attempts suggest that psychological and social crises in children can induce, and be induced by maternal psychosocial problems and vice versa.

This mother-child morbidity pattern suggests that psychosocial disorders are transferable between children and their mothers, if unmitigated. ${ }^{21,23,25,26}$ It is however important to note that, child and mother morbidities could happen independently, that is, not one inducing the other. 21,23,25 Whichever way it occurs, concurrent psychosocial morbidity is important in the sense that, it produces double burden on the family. It aggravates an 
Table IV: Distribution and influence of selected psychosocial factors among mothers who have probable psychiatric morbidity (SRQ scores $\geq \mathbf{5}$ )

\begin{tabular}{|c|c|c|c|c|c|c|c|c|c|c|}
\hline VARIABLES & & $\begin{array}{l}S C D \\
X=100 \\
x\end{array}$ & $\begin{array}{l}N=28 \\
n\end{array}$ & P value & $\begin{array}{l}\text { ASTHMA } \\
x=75 \\
x\end{array}$ & $\begin{array}{l}N=15 \\
n\end{array}$ & $P$ Value & $\begin{array}{l}A M l \\
X=75 \\
x\end{array}$ & $\begin{array}{l}N=19 \\
n\end{array}$ & P value \\
\hline Children's Rutter score & $\begin{array}{r}<7 \text { (None cases) } \\
\geq 7 \text { (Cases) }\end{array}$ & $\begin{array}{l}70 \\
30\end{array}$ & $\begin{array}{l}15 \\
13\end{array}$ & 0.046 & $\begin{array}{l}56 \\
19\end{array}$ & $\begin{array}{l}8 \\
7\end{array}$ & 0.048 & $\begin{array}{l}60 \\
15\end{array}$ & $\begin{array}{l}9 \\
10\end{array}$ & $\begin{array}{l}0.000 \\
0.000\end{array}$ \\
\hline Age Group in years & $\begin{array}{r}7-10 \\
11-14\end{array}$ & $\begin{array}{l}49 \\
51\end{array}$ & $\begin{array}{l}11 \\
17\end{array}$ & 0.323 & $\begin{array}{l}40 \\
35\end{array}$ & $\begin{array}{l}8 \\
7\end{array}$ & 0.772 & $\begin{array}{l}39 \\
36\end{array}$ & $\begin{array}{l}8 \\
11\end{array}$ & 0.463 \\
\hline Children's Gender & $\begin{array}{r}\text { Male } \\
\text { Female }\end{array}$ & $\begin{array}{l}52 \\
48\end{array}$ & $\begin{array}{l}19 \\
9\end{array}$ & 0.079 & $\begin{array}{l}40 \\
35\end{array}$ & $\begin{array}{l}8 \\
7\end{array}$ & 0.772 & $\begin{array}{l}41 \\
34\end{array}$ & $\begin{array}{l}11 \\
8\end{array}$ & 0.952 \\
\hline Children's level of education & $\begin{array}{r}\text { Primary } \\
\text { Secondary }\end{array}$ & $\begin{array}{l}66 \\
30\end{array}$ & $\begin{array}{l}17 \\
11\end{array}$ & 0.397 & $\begin{array}{l}46 \\
28\end{array}$ & $\begin{array}{l}11 \\
4\end{array}$ & 0.483 & $\begin{array}{l}47 \\
27\end{array}$ & $\begin{array}{l}12 \\
7\end{array}$ & 0.811 \\
\hline Type o f Family & $\begin{array}{r}\text { Monogamy } \\
\text { Polygamy }\end{array}$ & $\begin{array}{l}59 \\
40\end{array}$ & $\begin{array}{l}12 \\
15\end{array}$ & 0.099 & $\begin{array}{l}51 \\
24\end{array}$ & $\begin{array}{l}6 \\
9\end{array}$ & 0.014 & $\begin{array}{l}53 \\
22\end{array}$ & $\begin{array}{l}9 \\
10\end{array}$ & 0.022 \\
\hline Any hospital visits in 6 months & $\begin{array}{l}\text { Yes } \\
\text { None }\end{array}$ & $\begin{array}{l}92 \\
8\end{array}$ & $\begin{array}{l}26 \\
2\end{array}$ & 1.000 & $\begin{array}{l}26 \\
49\end{array}$ & $\begin{array}{l}8 \\
7\end{array}$ & 0.163 & $\begin{array}{l}26 \\
49\end{array}$ & $\begin{array}{l}7 \\
12\end{array}$ & 0.961 \\
\hline Any school days missed per term & $\begin{array}{l}\text { Yes } \\
\text { None }\end{array}$ & $\begin{array}{l}59 \\
39\end{array}$ & $\begin{array}{l}16 \\
12\end{array}$ & 0.870 & $\begin{array}{l}17 \\
58\end{array}$ & $\begin{array}{l}6 \\
9\end{array}$ & 0.091 & $\begin{array}{l}16 \\
59\end{array}$ & $\begin{array}{l}6 \\
13\end{array}$ & 0.214 \\
\hline Any previous hospital admissions & $\begin{array}{l}\text { Yes } \\
\text { None }\end{array}$ & $\begin{array}{l}77 \\
23\end{array}$ & $\begin{array}{l}23 \\
5\end{array}$ & 0.619 & $\begin{array}{l}14 \\
61\end{array}$ & $\begin{array}{l}3 \\
12\end{array}$ & 1.000 & $\begin{array}{l}8 \\
57\end{array}$ & $\begin{array}{l}2 \\
17\end{array}$ & 1.000 \\
\hline Interference with daily play activities & $\begin{array}{l}\text { Yes } \\
\text { No }\end{array}$ & $\begin{array}{l}67 \\
33\end{array}$ & $\begin{array}{l}19 \\
9\end{array}$ & 0.902 & $\begin{array}{l}45 \\
30\end{array}$ & $\begin{array}{l}9 \\
6\end{array}$ & 0.768 & $\begin{array}{l}32 \\
46\end{array}$ & $\begin{array}{l}6 \\
13\end{array}$ & 0.388 \\
\hline Interference with domestic activities & $\begin{array}{l}\text { Yes } \\
\text { No }\end{array}$ & $\begin{array}{l}56 \\
43\end{array}$ & $\begin{array}{l}18 \\
10\end{array}$ & 0.510 & $\begin{array}{l}37 \\
38\end{array}$ & $\begin{array}{l}7 \\
8\end{array}$ & 0.954 & $\begin{array}{l}28 \\
47\end{array}$ & $\begin{array}{l}6 \\
13\end{array}$ & 0.745 \\
\hline I feel I am a burden to my family & $\begin{array}{l}\text { Yes } \\
\text { No }\end{array}$ & $\begin{array}{l}33 \\
67\end{array}$ & $\begin{array}{l}10 \\
18\end{array}$ & 0.902 & $\begin{array}{l}19 \\
56\end{array}$ & $\begin{array}{l}7 \\
8\end{array}$ & 0.048 & $\begin{array}{l}10 \\
65\end{array}$ & $\begin{array}{l}6 \\
13\end{array}$ & 0.014 \\
\hline I feel that people bother me a lot & $\begin{array}{l}\text { Yes } \\
\text { No }\end{array}$ & $\begin{array}{l}27 \\
73\end{array}$ & $\begin{array}{l}11 \\
17\end{array}$ & 0.140 & $\begin{array}{l}10 \\
65\end{array}$ & $\begin{array}{l}5 \\
10\end{array}$ & 0.023 & $\begin{array}{l}9 \\
66\end{array}$ & $\begin{array}{l}4 \\
15\end{array}$ & 0.219 \\
\hline I feel people discriminate against me & $\begin{array}{l}\text { Yes } \\
\text { No }\end{array}$ & $\begin{array}{l}32 \\
68\end{array}$ & $\begin{array}{l}9 \\
19\end{array}$ & 0.826 & $\begin{array}{l}10 \\
65\end{array}$ & $\begin{array}{l}5 \\
10\end{array}$ & 0.023 & $\begin{array}{l}10 \\
65\end{array}$ & $\begin{array}{l}6 \\
4\end{array}$ & 0.014 \\
\hline Mother's age in years & $\begin{array}{r}<30 \\
31-40 \\
>40\end{array}$ & $\begin{array}{l}9 \\
59 \\
35\end{array}$ & $\begin{array}{l}1 \\
13 \\
14\end{array}$ & 0.110 & $\begin{array}{l}10 \\
42 \\
23\end{array}$ & $\begin{array}{l}2 \\
8 \\
5\end{array}$ & 0.967 & $\begin{array}{l}17 \\
41 \\
17\end{array}$ & $\begin{array}{l}5 \\
9 \\
5\end{array}$ & 0.761 \\
\hline Mother's level of education & $\begin{array}{r}\text { None } \\
\text { Primary } \\
\geq \text { Secondary }\end{array}$ & $\begin{array}{l}38 \\
21 \\
41\end{array}$ & $\begin{array}{l}13 \\
9 \\
6\end{array}$ & 0.030 & $\begin{array}{l}24 \\
12 \\
39\end{array}$ & $\begin{array}{l}10 \\
2 \\
3\end{array}$ & $\begin{array}{l}0.004 \\
18\end{array}$ & $\begin{array}{l}20 \\
3 \\
37\end{array}$ & $\begin{array}{l}8 \\
8\end{array}$ & 0.196 \\
\hline Occupational group of mothers & $\begin{array}{r}\text { Skilled } \\
\text { Semiskilled } \\
\text { Unskilled }\end{array}$ & $\begin{array}{l}17 \\
22 \\
58\end{array}$ & $\begin{array}{l}1 \\
7 \\
19\end{array}$ & 0.084 & $\begin{array}{l}14 \\
25 \\
35\end{array}$ & $\begin{array}{l}0 \\
4 \\
11\end{array}$ & 0.038 & $\begin{array}{l}17 \\
22 \\
33\end{array}$ & $\begin{array}{l}5 \\
5 \\
9\end{array}$ & 0.885 \\
\hline Mother's number of children & $\begin{array}{l}\leq 5 \\
\geq 6\end{array}$ & $\begin{array}{l}75 \\
25\end{array}$ & $\begin{array}{l}19 \\
9\end{array}$ & 0.440 & $\begin{array}{l}53 \\
22\end{array}$ & $\begin{array}{l}10 \\
5\end{array}$ & 0.755 & $\begin{array}{l}53 \\
21\end{array}$ & $\begin{array}{l}14 \\
5\end{array}$ & 0.966 \\
\hline Financial effect & $\begin{array}{l}\text { Yes } \\
\text { No }\end{array}$ & $\begin{array}{l}94 \\
6\end{array}$ & $\begin{array}{l}26 \\
2\end{array}$ & 0.671 & $\begin{array}{l}58 \\
17\end{array}$ & $\begin{array}{l}13 \\
2\end{array}$ & 0.496 & $\begin{array}{l}39 \\
36\end{array}$ & $\begin{array}{l}12 \\
7\end{array}$ & 0.389 \\
\hline Time Consumption & $\begin{array}{l}\text { Yes } \\
\text { No }\end{array}$ & $\begin{array}{l}90 \\
10\end{array}$ & $\begin{array}{l}26 \\
2\end{array}$ & 0.721 & $\begin{array}{l}48 \\
27\end{array}$ & $\begin{array}{l}11 \\
4\end{array}$ & 0.588 & $\begin{array}{l}38 \\
37\end{array}$ & $\begin{array}{l}13 \\
6\end{array}$ & 0.127 \\
\hline Disease preventing enjoyment of life & $\begin{array}{l}\text { Yes } \\
\text { No }\end{array}$ & $\begin{array}{l}59 \\
41\end{array}$ & $\begin{array}{l}18 \\
10\end{array}$ & 0.657 & $\begin{array}{l}21 \\
54\end{array}$ & $\begin{array}{l}4 \\
11\end{array}$ & 1.000 & $\begin{array}{l}17 \\
58\end{array}$ & $\begin{array}{l}5 \\
14\end{array}$ & 0.753 \\
\hline
\end{tabular}


Table V: Distribution and influence of selected psychosocial factors among children who have probable psychiatric morbidity (Rutter scale A2 $\geq 7$ )

\begin{tabular}{|c|c|c|c|c|c|c|c|c|c|c|}
\hline VARIABLES & & $\begin{array}{l}S C D \\
X=100 \\
x\end{array}$ & $\begin{array}{l}N=30 \\
n\end{array}$ & P value & $\begin{array}{l}\text { ASTHMA } \\
x=75 \\
x\end{array}$ & $\begin{array}{l}N=19 \\
n\end{array}$ & $P$ Value & $\begin{array}{l}A M l \\
X=75 \\
x\end{array}$ & $\begin{array}{l}N=15 \\
n\end{array}$ & $P$ value \\
\hline Mothers' SRQ Scores & $\begin{array}{r}\geq 5 \text { ( cases) } \\
<5 \text { (Non-cases) }\end{array}$ & $\begin{array}{l}28 \\
72\end{array}$ & $\begin{array}{l}13 \\
17\end{array}$ & 0.046 & $\begin{array}{l}15 \\
60\end{array}$ & $\begin{array}{l}7 \\
12\end{array}$ & 0.048 & $\begin{array}{l}19 \\
56\end{array}$ & $\begin{array}{l}10 \\
9\end{array}$ & 0.004 \\
\hline Mother's age in years & $\begin{array}{r}<30 \\
31-40 \\
>40\end{array}$ & $\begin{array}{l}9 \\
56 \\
35\end{array}$ & $\begin{array}{l}3 \\
20 \\
7\end{array}$ & 0.275 & $\begin{array}{l}10 \\
42 \\
23\end{array}$ & $\begin{array}{l}2 \\
8 \\
9\end{array}$ & 0.188 & $\begin{array}{l}17 \\
41 \\
17\end{array}$ & $\begin{array}{l}7 \\
5 \\
3\end{array}$ & 0.041 \\
\hline Mother's level of education & $\begin{array}{r}\text { None } \\
\text { Primary } \\
\geq \text { Secondary }\end{array}$ & $\begin{array}{l}38 \\
21 \\
41\end{array}$ & $\begin{array}{l}11 \\
5 \\
14\end{array}$ & 0.691 & $\begin{array}{l}24 \\
12 \\
39\end{array}$ & $\begin{array}{l}8 \\
6 \\
5\end{array}$ & 0.019 & $\begin{array}{l}20 \\
18 \\
37\end{array}$ & $\begin{array}{l}7 \\
3 \\
5\end{array}$ & 0.142 \\
\hline Occupational group of mothers & $\begin{array}{r}\text { Skilled } \\
\text { Semiskilled } \\
\text { Unskilled }\end{array}$ & $\begin{array}{l}17 \\
22 \\
61\end{array}$ & $\begin{array}{l}4 \\
9 \\
17\end{array}$ & 0.424 & $\begin{array}{l}14 \\
25 \\
36\end{array}$ & $\begin{array}{l}0 \\
6 \\
13\end{array}$ & 0.030 & $\begin{array}{l}17 \\
22 \\
36\end{array}$ & $\begin{array}{l}2 \\
6 \\
7\end{array}$ & 0.483 \\
\hline Type of family & $\begin{array}{r}\text { Monogamy } \\
\text { Polygamy }\end{array}$ & $\begin{array}{l}59 \\
40\end{array}$ & $\begin{array}{l}15 \\
14\end{array}$ & 0.422 & $\begin{array}{l}51 \\
24\end{array}$ & $\begin{array}{l}8 \\
11\end{array}$ & 0.012 & $\begin{array}{l}53 \\
22\end{array}$ & $\begin{array}{l}7 \\
8\end{array}$ & 0.030 \\
\hline Financial effect & $\begin{array}{l}\text { Yes } \\
\text { No }\end{array}$ & $\begin{array}{l}94 \\
6\end{array}$ & $\begin{array}{l}29 \\
1\end{array}$ & 0.665 & $\begin{array}{l}58 \\
17\end{array}$ & $\begin{array}{l}18 \\
1\end{array}$ & 0.055 & $\begin{array}{l}39 \\
36\end{array}$ & $\begin{array}{l}7 \\
8\end{array}$ & 0.862 \\
\hline Time Consumption & $\begin{array}{l}\text { Yes } \\
\text { No }\end{array}$ & $\begin{array}{l}90 \\
10\end{array}$ & $\begin{array}{l}29 \\
1\end{array}$ & 0.274 & $\begin{array}{l}48 \\
27\end{array}$ & $\begin{array}{l}15 \\
4\end{array}$ & 0.196 & $\begin{array}{l}38 \\
37\end{array}$ & $\begin{array}{l}8 \\
7\end{array}$ & 0.954 \\
\hline Disease preventing enjoyment of life & $\begin{array}{l}\text { Yes } \\
\text { No }\end{array}$ & $\begin{array}{l}59 \\
41\end{array}$ & $\begin{array}{l}18 \\
12\end{array}$ & 0.929 & $\begin{array}{l}21 \\
54\end{array}$ & $\begin{array}{l}6 \\
13\end{array}$ & 0.915 & $\begin{array}{l}17 \\
58\end{array}$ & $\begin{array}{l}3 \\
12\end{array}$ & 1.000 \\
\hline Children's age group in years & $\begin{array}{r}7-10 \\
11-14\end{array}$ & $\begin{array}{l}49 \\
51\end{array}$ & $\begin{array}{l}18 \\
12\end{array}$ & 0.222 & $\begin{array}{l}40 \\
35\end{array}$ & $\begin{array}{l}11 \\
8\end{array}$ & 0.845 & $\begin{array}{l}39 \\
36\end{array}$ & $\begin{array}{l}9 \\
6\end{array}$ & 0.686 \\
\hline Children's Gender & $\begin{array}{l}\text { Male } \\
\text { Female }\end{array}$ & $\begin{array}{l}52 \\
48\end{array}$ & $\begin{array}{l}18 \\
12\end{array}$ & 0.407 & $\begin{array}{l}40 \\
35\end{array}$ & $\begin{array}{l}11 \\
8\end{array}$ & 0.845 & $\begin{array}{l}41 \\
34\end{array}$ & $\begin{array}{l}11 \\
4\end{array}$ & 0.182 \\
\hline Children's level of education & $\begin{array}{r}\text { Primary } \\
\text { Secondary }\end{array}$ & $\begin{array}{l}66 \\
30\end{array}$ & $\begin{array}{l}20 \\
10\end{array}$ & 0.953 & $\begin{array}{l}46 \\
28\end{array}$ & $\begin{array}{l}11 \\
8\end{array}$ & 0.865 & $\begin{array}{l}47 \\
27\end{array}$ & $\begin{array}{l}12 \\
3\end{array}$ & 0.236 \\
\hline Any hospital visits in 6 months & $\begin{array}{l}\text { Yes } \\
\text { None }\end{array}$ & $\begin{array}{l}92 \\
8\end{array}$ & $\begin{array}{l}25 \\
5\end{array}$ & 0.050 & $\begin{array}{l}26 \\
49\end{array}$ & $\begin{array}{l}6 \\
13\end{array}$ & 0.961 & $\begin{array}{l}26 \\
49\end{array}$ & $\begin{array}{l}4 \\
11\end{array}$ & 0.671 \\
\hline Any school days missed per term & $\begin{array}{l}\text { Yes } \\
\text { None }\end{array}$ & $\begin{array}{l}59 \\
39\end{array}$ & $\begin{array}{l}14 \\
16\end{array}$ & 0.111 & $\begin{array}{l}17 \\
58\end{array}$ & $\begin{array}{l}6 \\
13\end{array}$ & 0.753 & $\begin{array}{l}16 \\
59\end{array}$ & $\begin{array}{l}7 \\
8\end{array}$ & 0.039 \\
\hline Any previous hospital admissions & $\begin{array}{l}\text { Yes } \\
\text { None }\end{array}$ & $\begin{array}{l}76 \\
24\end{array}$ & $\begin{array}{l}26 \\
4\end{array}$ & 0.168 & $\begin{array}{l}14 \\
61\end{array}$ & $\begin{array}{l}4 \\
15\end{array}$ & 0.743 & $\begin{array}{l}8 \\
67\end{array}$ & $\begin{array}{l}2 \\
13\end{array}$ & 0.657 \\
\hline Interference with daily play activities & $\begin{array}{l}\text { Yes } \\
\text { No }\end{array}$ & $\begin{array}{l}67 \\
33\end{array}$ & $\begin{array}{l}19 \\
11\end{array}$ & 0.781 & $\begin{array}{l}45 \\
30\end{array}$ & $\begin{array}{l}4 \\
15\end{array}$ & 0.551 & $\begin{array}{l}29 \\
46\end{array}$ & $\begin{array}{l}3 \\
12\end{array}$ & 0.173 \\
\hline Interference with domestic activities & $\begin{array}{l}\text { Yes } \\
\text { No }\end{array}$ & $\begin{array}{l}56 \\
43\end{array}$ & $\begin{array}{l}18 \\
12\end{array}$ & 0.815 & $\begin{array}{l}37 \\
38\end{array}$ & $\begin{array}{l}13 \\
6\end{array}$ & 0.946 & $\begin{array}{l}28 \\
47\end{array}$ & $\begin{array}{l}4 \\
11\end{array}$ & 0.512 \\
\hline I feel I am a burden to my family & $\begin{array}{l}\text { Yes } \\
\text { No }\end{array}$ & $\begin{array}{l}33 \\
67\end{array}$ & $\begin{array}{l}11 \\
19\end{array}$ & 0.781 & $\begin{array}{l}19 \\
56\end{array}$ & $\begin{array}{l}10 \\
9\end{array}$ & 0.765 & $\begin{array}{l}10 \\
65\end{array}$ & $\begin{array}{l}6 \\
9\end{array}$ & 0.003 \\
\hline I feel that people bother me a lot & $\begin{array}{l}\text { Yes } \\
\text { No }\end{array}$ & $\begin{array}{l}27 \\
73\end{array}$ & $\begin{array}{l}6 \\
24\end{array}$ & 0.409 & $\begin{array}{l}10 \\
65\end{array}$ & $\begin{array}{l}4 \\
15\end{array}$ & 0.110 & $\begin{array}{l}9 \\
66\end{array}$ & $\begin{array}{l}4 \\
11\end{array}$ & 0.072 \\
\hline I feel people discriminate against me & $\begin{array}{l}\text { Yes } \\
\text { No }\end{array}$ & $\begin{array}{l}32 \\
68\end{array}$ & $\begin{array}{l}11 \\
19\end{array}$ & 0.674 & $\begin{array}{l}10 \\
65\end{array}$ & $\begin{array}{l}5 \\
14\end{array}$ & 0.707 & $\begin{array}{l}10 \\
65\end{array}$ & $\begin{array}{l}7 \\
8\end{array}$ & 0.000 \\
\hline
\end{tabular}


already difficult situation caused by the disease. If not handled carefully, it could cause further distress for the whole family, and sometimes lead to severe complications such as marital discord or even divorce. ${ }^{13,17,18}$

Furthermore, it can adversely affect the manageability of the child's physical disease by increasing costs (time and money) and undermining compliance; a consequence of the significant role played by mothers when their children are ill. ${ }^{7,23-25}$ Moreover, it is more likely that subsisting problems in the mother will adversely affect the physical and psychosocial care of the child, and the family as a whole. Therefore, it is important to identify concurrent psychosocial morbidity irrespective of aetiology and deal with it; although, it is even better to prevent it.

Factors that were associated with significant risk of a mother having SRQ scores $\geq 5$ and her child having CBQ score $\geq 7$ were considered as correlate of concurrent psychosocial morbidity. Modifiable correlates can be changed or controlled by life style modification and behaviour adjustments; non-modifiable factors require awareness of problems and readiness to contain them. No correlate was identified that was significant across the three groups (Tables IV and V). This probably suggests that concurrency may be a largely disease specific phenomenon which needs further exploration. "Family type" had a significant association in the Asthma and AMI groups, that is, children and mothers from polygamous backgrounds were at higher risk. In the asthma group "mothers' education" was an additional risk factor (mothers with lower education were at higher risk). And in the AMI group 'feeling of being a burden to the family" and 'feeling that people discriminate against me" were two additional risk factors. Polygamy as practiced in the study environment is known to be a psychosocial stressor, often linked to family and marital disharmony. ${ }^{37,38}$ It is a complex modifiable factor rooted in culture and religion that would require effective communication and education to modify. However, it is a factor worth exploring in a larger study to have conclusive evidence of its effects.

While not all children and mothers reported adverse social effects from these diseases, an indication that they may be coping with their problems, the majority of them reported problems in virtually all the psychosocial variables considered (Tables II and III). Overall, SCD produced adverse social effects most frequently; children with SCD and their mothers had significantly greater burden than Asthma and AMI. This was expected in view of its more severe and debilitating nature. The management of SCD requires that children attend special clinics whether they are ill or not, combined with the experience of intermittent episodes of crises, hospital admissions, and occasional blood transfusion, a lot of stress is generated and psychosocial dysfunction is made more probable.

In a number of psychosocial variables SCD was not significantly different from Asthma and AMI (Table II and III); of note is CBQ score of the children and SRQ scores of their mothers which was not significantly different in the three groups. Examining the reason for this unexpected pattern is imperative. While this could mean that all the diseases were merely similar in respect of these variables; similarities in family environment and medical care may have leveled the expected differences in these psychosocial variables.

Nonetheless, this pattern may also suggest the existence of other, yet to be identified factors, unrelated to severity, which may have lowered the burden of SCD as measured by affected variables, thus this convergence or similarity. More comprehensive report of the psychological and social effects of SCD on children and their mothers has been made elsewhere. ${ }^{39}$

\section{Conclusion}

Psychosocial problems occurring concurrently in children and their mothers is a phenomenon that has implications for preventive psychiatry. This study suggests that children should be seen in the context of their families holistically; and that the bio psychosocial approach to health care and consultation-liaison psychiatry should be emphasized. This phenomenon needs further investigation in this environment to ensure prompt intervention and avoidable suffering of children and their mothers.

Whenever a child or mother is identified to have psychosocial problems the minimum of psychosocial assessment should include both parent and child in order to detect any concurrency early. If possible, other members of the family should be assessed too; since mothers are often the ones who accompany their children to the clinics they are more accessible for combined assessment. Combined psychosocial therapy of children and their mothers is more likely to have a better success than treating the child alone when mother is unknowingly the problem.

\section{References}

1. Adeyokunnu A. Control of sickle cell disease. In: Sofoluwe GO and Bennet FJ, Eds. Principle and Practice of Community Health in Africa. Ibadan, University Press 1985: 309-319.

2. Ohaeri JU, Sokunbi WA, Akinlade KS, Dare LO. The psychosocial problems of sickle cell disease sufferers and their methods of coping. Soc Sci Med 1995; 40(7): 955-960.

3. Omotade OO. Controlling sickle cell anaemia through genetic counseling. Afr Health 1989: 42-43.

4. Konotey-Ahulu FE. Sickle cell disease: The case for family planning. Modified from materials first presented at the legal workshop of the 2nd international conference on voluntary sterilization Feb. 25-March 1, 1973, Geneva. Under the title of sickle cell disease: case for voluntary sterilization law? Accra Ghana, Astab Limited, 1973: 1-32.

5. Pless IB, Roghmann KJ. Chronic illness and its consequences observation based on three epidemiological surveys. J Pediatr 1971; 79(3): 351-359.

6. Pless IB, Clinical assessment: Physical and psychological functioning, symposium on chronic diseases in children. Pediatr Clin North Am 1984; 31 (1): 33-45.

7. Sabbeth B, Understanding the impact of chronic childhood illness on families. Symposium on chronic diseases in children. Pediatr Clin North Am 1984; 31 (1): 47-57.

8. Carey WB, Sibinga MS. Avoiding paediatric pathogenesis in the management of acute minor illness. Pediatrics 1972; 49(4): 553561.

9. Mattson A. Long term physical illness: A challenge to social adaptation. Pediatrics 1972; 50(5): 801-811.

10. Hamlett KW, Pellegrini DS, Katz KS. Childhood chronic illness as a 
family stressor. J Pediatr Psychol 1992; 17(1): 33-47.

11. Sharpiro J. Family reactions and coping strategies in response to the physically ill or handicapped child: A Review. Soc Sci Med 1983; 17(14): 913-931

12. Barbarin $O A$, Whitten CF. and Bonds SM. Estimating rates of psychosocial problems in urban and poor children with sickle cell anaemia. Health Soc Work 1994; 19(2): 112-9.

13. Bamisaiye A, Bakare CGM, Olatawura MO. Some sociopsychologic dimension of sickle cell anaemia among Nigerians. Clin Pediatrics 1974; 13(1): 56-59.

14. Famuyiwa OO, Asuni T. A standard schedule for burden on the family of sickle cell anaemia sufferers. J Trop Med and Hygiene 1991; 94:277-282

15. Smilkstein G. The family APGAR: A proposal for a family function test and its use by physicians. J Family Practice 1978; 6(6): 1231 1239 .

16. Leventhal JM. Psychosocial assessment of children with chronic physical disease: Symposium on chronic disease in children. Pediatr Clin North Am 1984; 31 (1): 71-86.

17. Adeodu OO, Adekile AD, Alimi T. The child with sickle cell anaemia: Effects of the disease on intra family ties and emotional status Abstracts of proceeding of 26 th Annual Conference of the Paediatric Association of Nigeria, Sagamu. Niger J Paediatr 1995; 22(3): 67-84

18. Abiodun OA. Psychosocial complications and management of sickle cell disease. East Afr Med J 1993; 70(1): 40-42.

19. Aderele WI. Bronchial asthma in Nigerian children. Arch Dis Child 1979; 54: 448-453

20. Gelder M, Gath D, Mayou R, Cowen P. Oxford Textbook of Psychiatry. 3rd edition: Oxford, 2000: 668-669.

21. Garmezy N, Mastern AS. Chronic Adversities. In: Rutter M, Taylrsor E, Hersov L, eds. Child and Adolescent Psychiatry: A Modern Approach, 3rd edn. Oxford, Blackwell Scientific publications 1994: 191-208

22. Foreman DM. Maternal mental illness and mother-child relations Adv Psychiatr Treatment 1998; 4: 135-143.

23. Weissman MM, Pilowsky DJ, Wickramaratne PJ, Talati A, Wisniewski SR, Fava M, et al. Remissions in maternal depression and child psychopathology. A star*D-Child Report. JAMA 2006, 295: 1389-1398.

24. Marmorstein NR, Malone SM, Iacono WG. Psychiatric disorders among offsprings of depressed mothers: Associations with paternal psychopathology. Am J Psychiatry 2004; 161:1588-1594.

25. Gordon D, Burge D, Hammen C, Adrian C, Jaenicke C, Hiroto D. Observations of interactions of depressed women with their children. Am J Psychiatry 1989; 146: 50-55.

26. Rutter M. Children of sick parents: An environmental and psychiatric study. Oxford University press Oxford 1966

27. Iloeje SO. Psychiatric morbidity among children with sickle cell disease. Dev Med and Child Neurology 1991; 33: 1087-1094.

28. Kumar S, Powars D, Allen J, Haywood LJ. Anxiety, Self concept, and Personal and Social adjustments in children with sickle cell anaemia. J Pediatrics 1976; 88(5): 859-863.

29. Tunde-Ayinmode MF. Psychosocial impact of sickle cell disease on children and their mothers in University of Ilorin Teaching Hospital: A controlled study. Dissertation submitted to the National Postgraduate Medical College of Nigeria in fulfilment of the award of Fellowship of the Faculty of Psychiatry. 1999.

30. Rutter M, Tifard J, Whitemore KL. Education Health Behaviour. London Longmans, 1970

31. Harding TW, DeArango MV, Baltazar J, Climent CE, Ibrahim HHA, Ladrido- Ignacio L, et al. Mental disorders in primary health care: A study of their frequency and diagnosis in four developing countries. Investigation in a WHO collaborative study on strategies for extending mental health care. Psychol Med 1980; 10: 231-241

32. Boyle MH, Jones SC. Selecting measures of emotional and behavioural disorders of childhood for use in general populations. J Child Psychol Psychiatry 1985; 26(1): 137-159.

33. Rutter M, Yule W, Berger M., Yule B, Morton J, Bagley C. Children of West Indian Immigrants - 1: Rates of behavioural deviance and of psychiatric disorder. J Child Psychol Psychiatry 1974; 15:241262

34. Omigbodun OO. Screening children for psychiatric morbidity in primary care: Selecting appropriate instrument. Dissertation submitted to the West African College of Physician in fulfilment of the award of fellowship of the Faculty of Psychiatry. 1991: 91-108.

35. Abiodun $O A$, Sensitivity and validity of the Self Reporting Questionnaire (SRQ) in a primary health care centre in rural community in Nigeria. Psychopathologie Africanie 1988-1989; 22(1): 79-88.

36. Ohaeri JU, Odejide OA, Gureje O, Olatawura MO. Psychiatry morbidity among children attending health facilities in primary health care in a rural Nigeria community. Niger Med J 1994; 26(3): 93-95.

37. Oyewumi LK. Inpatient adolescent psychiatry in a Teaching Hospital in Nigeria. Acta Psychiatr Scand 1989; 80: 639-643.

38. Adelekan ML. Psychiatric disorders of children and young adults in developing countries. In: Tantam D, Appleby L, Duncan A. Eds. Psychiatry for the Developing World. Imprints of Royal College of Psychiatrists. London 1995: 311-340.

39. Tunde-Ayinmode MF,Adelekan ML. Psychosocial impact of sickle cell disease in children seen at University of Ilorin Teaching Hospital, Ilorin, Nigeria. East Afr Med J 2005; 2:73-78.

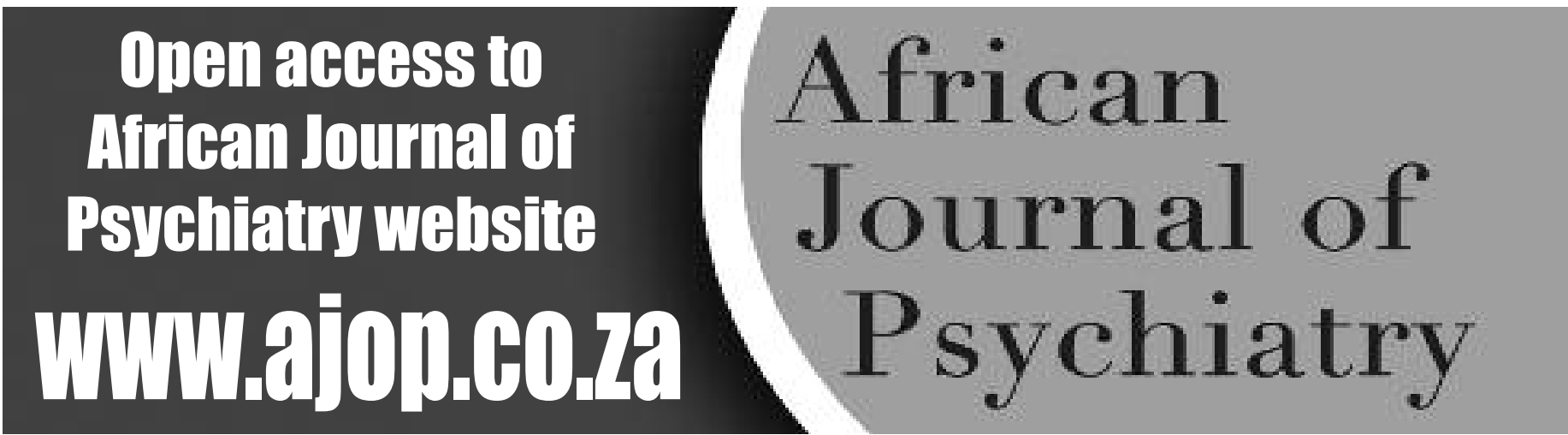

